\title{
16
}

\section{Nuclear-free New Zealand: Contingency, contestation and consensus in public policymaking}

\author{
David Capie
}

\section{Introduction}

On 4 June 1987, the New Zealand Parliament passed the New Zealand Nuclear Free Zone, Disarmament and Arms Control Act by 39 votes to 29. The legislation marked the culmination of a decades-long effort by a disparate group of peace and environmental activists to prevent nuclear weapons from entering New Zealand's territory. More than 30 years later, the law remains in force, it has bipartisan support and it is frequently touted as a key symbol of New Zealand's national identity.

In some ways, it should be puzzling that New Zealand has come to be so closely associated with staunch opposition to nuclear arms. The country is far removed from key strategic territory and even at the height of the Cold War was one of the least likely countries anywhere to suffer a nuclear attack. The fact the adoption of the antinuclear policy led to the end of New Zealand's alliance relationship with the United States under the Australia, New Zealand, United States Security (ANZUS) Treaty-an agreement once described as the 'richest prize' in New Zealand diplomacy-only adds to the puzzle (Catalinac 2010). How, then, did a group of activists 
and politicians propel an issue into the public consciousness and, despite the staunch opposition of the most powerful country in the world, work to see it enshrined in legislation?

This chapter explores nuclear-free New Zealand as an example of a policy success. It does so in four parts. First, it examines the social and political contexts in which the policy emerged. Unlike some cases in this book, there was no single moment of 'design' when the nuclear-free policy was created in response to a clearly defined problem. Rather, opposition to nuclear weapons and nuclear power evolved over decades and advocates pressed for a number of different policy initiatives. In the 1970s and 1980s, the idea that New Zealand should be nuclear-free found a new political class willing to embrace it and take it to the heart of electoral politics. Even then, it took some contingent events to generate widespread public support and become law.

Second, the chapter considers the decision to embed the nuclear-free policy in legislation. Why was this path taken when previous governments had been happy to issue statements of declaratory policy? What made a legislative commitment—something strongly opposed by New Zealand's allies - the preferred option? I argue that the nuclear-free case reminds us that even chaotic policymaking processes can produce powerful policy. Third, the chapter explores the nuclear-free policy's durability and legitimacy. How has a policy that was opposed by all of New Zealand's closest security partners and one of the country's two major political parties come to have deep bipartisan support? And how have New Zealand's antinuclear 'credentials' been used by successive governments as a way of branding the country and giving it a special voice in international affairs?

Before exploring the origins of New Zealand's nuclear-free movement, it is necessary to clarify precisely what policy success is under consideration here. Different parts of what is sometimes assumed to be a monolithic 'antinuclear movement' had quite distinct goals as they agitated for action from successive governments in the decades before 1987 (Leadbeater 2013). Some sought to prevent nuclear-armed vessels from entering New Zealand territory. Others were equally concerned about the perceived risks of nuclear energy, especially the nuclear propulsion systems used on ships and submarines. Some advocates argued nuclear-free was a policy designed only for New Zealand and 'not for export', while others felt New Zealand should also advocate internationally for complete nuclear disarmament—a goal that clearly remains elusive. 
For the purposes of this chapter, I will focus on the substance of the policy embedded in the 1987 legislation-namely, a legal prohibition on nuclear weapons and nuclear-powered vessels entering New Zealand. Where did this policy come from? How did it become law? And what has made it popular, durable and legitimate? I argue that, if policy successes can be measured by reference to programmatic, process, political and endurance aspects, the nuclear-free policy was far from successful in programmatic or process terms. However, it has been astonishingly successful in political terms and has proved remarkably durable.

\section{Identifying the problem, demanding a response}

New Zealanders' antipathy to nuclear weapons can be traced back to the early Cold War. While the use of atomic bombs against Hiroshima and Nagasaki to end World War II was generally welcomed by a warweary public, testing of nuclear weapons-especially more powerful thermonuclear weapons - in the Pacific Ocean gradually began to provoke opposition from across New Zealand society. High-yield American atmospheric tests in Micronesia created effects visible even thousands of kilometres away. David Lange (1990: 10) remembered that, when he was young, one test turned the sky over Auckland blood red and caused it to pulse with red and white beams of light, leaving him with 'a chill sense of dread'.

The 15-megaton American 'Castle Bravo' test, which destroyed Bikini Atoll and contaminated the Japanese fishing vessel Lucky Dragon in March 1954, sparked a new public consciousness about the effects of radioactive fallout. It provided 'the key impetus for the emergence of [an] anti-nuclear weapons movement in many countries', including New Zealand (Rudig 1990: 54-5). As Malcolm Templeton notes, from April 1954 onwards, there was a dramatic increase ... in the correspondence [about this issue] received by the Prime Minister from organisations and private citizens in New Zealand'. The opposition came from a broad swathe of society: '[C]hurches, trade unions, Labour Party branches and individuals wrote letters or signed petitions calling for a ban on testing and on the H-bomb itself' (Templeton 2006: 66). 
If there was modest but steadily growing opposition to American and British nuclear testing, antipathy intensified in 1962 when France indicated it would relocate its nuclear testing program from the Sahara Desert to French Polynesia. The New Zealand embassy in Paris was told to inform the French Government that testing in the Pacific 'would arouse greater concern' than US and UK testing at Christmas and Johnston islands

because there is less obvious need for such tests in the interests of Western security and because there could be greater risk of fallout drifting to New Zealand territory and Western Samoa. (Templeton 2006: 108)

In August 1963, more than 80,000 New Zealanders signed a petition asking the government to take the necessary steps to 'ban the bomb south of the line' and keep the southern hemisphere free of nuclear arms (McKinnon 1999: 148). The Federation of Labour together with the Methodist Church began to organise a boycott of French goods (Templeton 2006: 117).

A central driver of the early antinuclear protest movement was fear of the health and environmental consequences of testing. While the New Zealand Government provided naval assistance to British 'Grapple' tests in the Gilbert and Ellice Islands (now Kiribati), it also sought assurances that fallout from the tests posed no threat to New Zealand (Maclellan 2018: 205-19). Concerns about pollution from French atmospheric testing at Moruroa led to public anger when higher than normal levels of strontium-90 were found in milk in Samoa and New Zealand in the late 1960s (Williams 2016). By the 1970s, a thriving environmental movement, including groups such as Greenpeace and Friends of the Earth, had adopted the issue. In 1971, the National Party Government told the United States it would not accept visits by nuclear-powered ships until Washington agreed to accept liability in the event of a nuclear accident. Congressional legislation accepting such liability was passed in 1974, but Labour was in power by then and the government decided not to invite any warships into New Zealand waters. A further symbol of the growing concern about the risk posed by nuclear power came in 1976, when a petition presented under the banner of the "Coalition for Non-Nuclear Futures' and signed by 333,000 people was presented to parliament.

If concerns about the health and environmental risks posed by nuclear testing and energy dominated the early years of New Zealand's antinuclear movement, fears of nuclear war between the major powers began to play a greater role as the Cold War went on. In the late 1950s, the first 
New Zealand branches of the Campaign for Nuclear Disarmament (CND) were formed, inspired by the British peace movement's Easter March to the nuclear weapons facility at Aldermaston (Locke 1992: 170). Kevin Clements (2015: 101) says the New Zealand branches of the CND were 'initially very imitative' and their appeal to younger people benefited from the radical reputation of the British movement. The New Zealand CND grew dramatically from 1961 to 1963 and began to focus its advocacy on one policy goal: the creation of a nuclear-free zone in the southern hemisphere. New Zealand towns and cities began to declare themselves 'nuclear-free' following similar moves overseas. The Holyoake Government remained unenthusiastic, but the 1963 Partial Test Ban Treaty banned most atmospheric tests and took some of the energy out of the protests. (It was quickly revived by the resumption of French testing in Polynesia in 1966.)

Concerns about the threat of nuclear war reached a peak in the early 1980s. After the détente of the 1970s, the Soviet invasion of Afghanistan and the election of Ronald Reagan as US president launched a renewed phase of strategic confrontation between the United States and the Soviet Union, with a concomitant fear of catastrophic war. Reagan's use of the rhetoric of the 'Evil Empire' and jokes such as the infamous 'we begin bombing in five minutes' served only to increase tensions.

The 'new Cold War' of the early 1980s included the development of counterforce strategies to fight a limited nuclear war and the deployment of new weapons such as the MX missile. Washington had plans to test fire the MX with a splashdown in the Tasman Sea in 1983 but, after a backlash from parts of the Australian Labor Party and peace groups, eventually withdrew the plans. The US decision to deploy short-range Pershing II and cruise missiles in West Germany similarly prompted huge public protests organised by the CND. There can be little doubt about the role of the European peace movement in inspiring its New Zealand counterparts. Peace groups began to argue that the transit of nuclear weapons through New Zealand on US vessels made the country complicit in the doctrine of 'mutually assured destruction' and even made New Zealand a nuclear target. The theory of 'nuclear winter' also found followers, raising the possibility that New Zealand's remote location would not spare it from the destruction from a limited nuclear war in the northern hemisphere (Mydans 1988). 
This convergence of health, environmental and strategic concerns prompted what Kennedy Graham (1987: 223) has called a 'metamorphosis' in New Zealanders' threat perceptions. A country that for most of its history had sought protection from a great and powerful state increasingly asked itself whether its alliance with the United States brought greater risks than rewards. A 1986 defence committee of inquiry established by the government carried out a survey asking people what they regarded as the 'greatest present worry'. Nuclear war was identified by 48 per cent of respondents as the greatest threat to New Zealand ( 55 per cent of younger people) compared with just 11 per cent who feared an armed invasion of the country (Clements 2015: 158).

\section{The social and political contexts}

If there was a growing sense of public opposition to nuclear weapons, New Zealand governments were still cautious about protesting too vigorously or enacting measures that might upset relations with important international powers. This began to change in the early 1970s with the emergence of a group of activists and politicians who came of political age during the second half of the 1960s. This group included some influential figures in the fourth Labour Government, including Helen Clark, Jim Anderton, Richard Northey and Phil Goff.

The most important issue uniting these groups was opposition to the Vietnam War, which 'raised important questions about New Zealand's role in the world and about the relationship with the United States that lay at the heart of its post-war foreign policy' (Rabel 1991: 96). Again, Clements (2015) notes that many of the New Zealand protests were derivative, including the antiwar 'teach-ins' inspired by US groups such as Students for a Democratic Society. But, alongside Vietnam, a broader range of social issues also mobilised young people and caused them to demand the country move in a new political direction. These included environmentalism (such as the campaign to prevent the use of Lake Manapouri for a massive hydroelectricity project), demands for women's equality and greater rights for Māori and new Pacific migrants. As Rabel (1991: 99) puts it: '[T] hese issues and the groups that now promoted them could not be easily accommodated by the old political order.' 
Jock Phillips similarly identifies the emergence of an influential minority who were increasingly important in shaping New Zealand opinion:

Over half of the 1987 Labour MPs had previously been teachers, lecturers, researchers, scientists or broadcasters-people who were concerned with transmitting ideas ... These people came to political power in 1984 with the youngest and best-educated cabinet in New Zealand's history; they replaced an administration that in its early years had contained seven people who fought in World War II. (Phillips 1991: 195)

This group embodied a new nationalism based on New Zealand's South Pacific identity. This, Phillips says:

[C]hanged our perception of the threats to New Zealand. Communist China, Soviet Russia, and Communism in Southeast Asia do not seem like credible dangers. They are seen as inhabiting a very distant and different world. Instead, when we look out to the South Pacific we see the looming shadow of France exploding atomic bombs and suppressing the Kanak movement; we look upon American ships and bombs as dangerous and unnecessary interlopers in this part of the world. (Phillips 1991: 197)

Gerald Hensley (2013: 207), who served as a senior official to prime ministers Lange and Sir Robert Muldoon and was an avowed opponent of the nuclear-free policy, comes to a similar conclusion, saying, 'there is no doubt the ANZUS quarrel marked a revolution in New Zealand's outlook on the world'. This was part of a broader political shift. It included the sense of shock brought about by the United Kingdom's entry into the European Common Market in 1973, as well as public opposition towards the war in Vietnam.

$[T]$ he changes in foreign policy were the manifestations and not the drivers of a deeper shift in national attitudes. Over the previous decade a comfortable national consensus had splintered into warring fragments, in angry arguments over economic policy, the environment, women's rights, the meaning of the Treaty of Waitangi and even that patriotic icon, rugby football. New Zealand's old image of itself had gone for good; something new and equally compelling was needed to take its place. An uneasy nationalism floated in the air, like gas in a mine, and ANZUS was the spark that touched it off. Foreign policy became the battleground in the war for a new national identity. (Hensley 2013: 305) 


\section{Contingency}

The salience of a problem also owes much to contingency, and several events in the late 1970s and 1980s had a dramatic effect on the way New Zealanders saw the nuclear issue, giving the issue much greater public prominence and also widening the group of people opposed to nuclear power and weapons testing.

One such factor was a series of highly publicised accidents that released radioactive pollution into the atmosphere and called into question the safety of civilian reactors. These included the Three Mile Island leak in Pennsylvania in March 1979, which led to the creation of a 32-kilometre evacuation zone and eventually cost more than US\$1 billion to clean up. Much worse was to come in April 1986, when an explosion at the Chernobyl nuclear power plant in Ukraine killed between 30 and 50 people, forced more than 100,000 to flee and led to the release of a radioactive cloud across Western Europe. It was the first accident to be rated a level seven (the highest possible) incident on the International Atomic Energy Agency's Nuclear Event Scale. ${ }^{1}$

A second pivotal event was the bombing of the Greenpeace vessel Rainbow Warrior in Auckland harbour on 10 July 1985, which killed a Portuguese photographer on board. This was quickly exposed as an act of state terrorism carried out by agents of the French Directorate-General for External Security. The New Zealand public-already angry about French nuclear testing-was outraged. The failure of the United States or the United Kingdom to condemn the French actions (the Wall Street Journal published an editorial sympathising with the French) further rankled and fed a sense that New Zealand was being picked on by the big powers (Capie 2009: 593). As Kevin Clements (2015: 116) put it, the bombing

generated considerable public antagonism towards France, boosted support for the independence movement in New Caledonia/Kanaky, and reminded people of the contemptuous way in which French authorities had handled regional opposition towards the French Pacific nuclear programme for over twenty years.

1 A senior figure close to prime minister Jim Bolger was once asked why National had changed its position just weeks before the 1990 election and decided to support the nuclear-free policy. His oneword reply was: 'Chernobyl' (Author's conversation with former New Zealand official, 27 September 2018). 


\section{Design and choice}

The election of the fourth Labour Government brought together this issue and a new generation of highly motivated politicians willing to question many longstanding orthodoxies in New Zealand's foreign and defence policy. It also coincided with a range of extraordinary events that generated greater public support for a nuclear-free stance as a manifestation of a new nationalism. But this convergence does not, on its own, explain the decision to enshrine the nuclear-free policy in law.

There were various efforts to express a nuclear-free policy over several decades before the passage of the New Zealand nuclear-free zone legislation in 1987. In 1957, responding to a comment by the British defence minister that it might be necessary to deploy nuclear weapons to defend members of the Southeast Asia Treaty Organization, then deputy prime minister Keith Holyoake said New Zealand would not be a base for the storage of nuclear weapons. Six years later, this time as prime minister, Holyoake repeated the commitment that the country would not acquire, use or store nuclear weapons. New Zealand's early ratification of the 1968 Nuclear Non-Proliferation Treaty turned those commitments into a formal legal obligation (Templeton 2006: 147).

However, these statements notwithstanding, New Zealand's opposition to nuclear weapons remained partial and waxed and waned depending in part on which party was in power. In 1963, the National Government voted against a UN resolution calling for the prohibition of nuclear weapons. Throughout the 1960s, 1970s and 1980s, US naval vessels capable of carrying nuclear weapons visited New Zealand ports. Indeed, it is widely believed, although has never been officially confirmed, US ships carrying nuclear weapons made port calls during this period. Governments from both major parties issued annual 'blanket approvals' for US ship visits, apart from those that were nuclear powered. In 1976, prime minister Muldoon said in response to a question about nuclearpropelled vessels that

the warships that will visit New Zealand ports may well carry nuclear weapons of the tactical or short-range variety but so do conventionally powered warships. They do not carry long-range ballistic missiles. Such missiles are carried only by strategically armed submarines which will not come to New Zealand. (White 1997: 8; emphasis added) 
As Robert White (1997: 8) notes, these remarks 'got him [Muldoon] into trouble with the Americans ... concerned in case he was saying that no American submarines would be allowed to visit, a confusion he hastily corrected'. A note from the prime minister's department in October 1983 concerning the planned visit of the nuclear-powered submarine USS Phoenix said: '[I]t is almost certainly equipped with anti-submarine missiles, some of which probably have nuclear warheads on them' (cited in White 1997: 11).

There were several attempts to enact a nuclear-free policy in legislation prior to 1987, although none was successful. In August 1983, the leader of the small Social Credit Party, Bruce Beetham, introduced a Bill with such an aim, which was referred to a parliamentary select committee. Labour MP Richard Prebble then introduced his own Nuclear Free New Zealand Bill. The vote in parliament saw two government MPs cross the floor to support the opposition and, although the Bill was defeated by one vote, it prompted then prime minister Muldoon to call the snap election in which the Lange Labour Government was elected.

There were at least two distinct reasons peace activists and some in the Labour Party wanted the nuclear-free policy enshrined in legislation. First, the National Party pledged that if it were reelected it would ensure New Zealand rejoined ANZUS. It claimed it would be doing so while upholding the antinuclear position, although precisely how it would achieve this was never persuasively explained, other than by saying National would trust the United States and United Kingdom to respect New Zealand Government policy. Unsurprisingly, the nuclear-free movement was not willing to go along on this basis. Setting the policy down in law would obviously make it harder for it to be overturned in the future.

Second, those in the peace movement and on the left of the Labour Party were also suspicious about the commitment to the policy of some in the Lange Government (Clements 2015: 132-4). This was particularly the case between the election in July 1984 and early 1985, when there were exploratory efforts to see whether a compromise might be found that would allow US ships to visit, without requiring Washington to breach its policy of neither confirm nor deny. Lange certainly gave US officials the impression he was open to a compromise that would allow US vessels to visit New Zealand if the government could conclude they were not nuclear armed (Lange was also well known to be less concerned about nuclear propulsion). As part of these efforts, by late 1984, the United 
States had agreed to send a vessel to test the legislation. The USS Buchanan, a Charles F. Adams-class frigate, was not nuclear powered and almost certainly not nuclear armed. However, Lange did not share information about the vessel or the proposed visit with his Cabinet colleagues and instead disappeared for a visit to Tokelau, where he was incommunicado.

Some in the party worried Lange was going to water down the nuclearfree policy. On 24 January 1985, Margaret Wilson, president of the Labour Party, met with backbench MPs Clark, Wilde and Anderton, and they agreed with a formulation that would leave no room for ambiguity about whether a ship was nuclear armed. The next day, the Labour Party National Executive endorsed the definition, which demanded that any ship would be banned from New Zealand waters if it were 'capable of carrying nuclear weapons' (Wilson 1989: 65). In her memoir, Wilson recalls: '[I]t seemed important to us [the National Executive of the Labour Party] to remain firm that there was no compromise, there was no ability to negotiate policy.' Helen Clark had the same aim. Interviewed by Michael Bassett (2002), Clark said the plan was 'to lock the Government into its policy'.

Lange returned to New Zealand from Tokelau on 28 January and went immediately into a Cabinet meeting where he discovered his colleagues were now interpreting the nuclear-free policy as a ban on any vessels capable of carrying nuclear weapons. The USS Buchanan's antisubmarine rockets meant it was capable of carrying weapons, even if the official advice from the defence department and the External Intelligence Bureau was that it was unlikely to be doing so. This notwithstanding, the strict interpretation pressed by Wilson and her colleagues prevailed. Lange lamented later that he found himself 'in a minority of one' (Hensley 2013: 109). Opposed by the broader caucus and the Labour Party leadership, Lange dropped his plans for compromise. The Buchanan was denied entry. When the US refused to nominate another vessel, the die was cast. In February, a relatively junior US state department official, Bill Brown, was sent to meet the New Zealand prime minister while he was in Los Angeles to inform him the United States was ending most forms of intelligence and military cooperation with New Zealand. 


\section{Legitimacy and endurance}

The Nuclear Free New Zealand Act passed its third reading in parliament on 4 June 1987 and became law. On 15 August, Labour was returned to power in a landslide, winning 57 of the 97 seats. The nuclear issue was a major issue dividing the parties during the campaign, with National Party leader Jim Bolger calling the law 'an exercise in futility' and saying it did nothing to advance arms control or protect New Zealand from nuclear weapons (Evans 1987). National retained its opposition to the law until a few weeks before the 1990 election, when, worried by tightening polls, it reversed its policy, leading its defence spokesperson Don McKinnon to resign in protest.

Although National won the 1990 election, the prohibition against nuclear weapons remained uncontested. This was helped by the decision of the US administration of George H. W. Bush in 1991 to remove nuclear weapons from all US surface vessels. The challenge posed by the policy of 'neither confirm nor deny' was no longer relevant; the only obstacle to a resumption of visits was the ban on nuclear propulsion. Clearly of a mind to change this, the Bolger Government appointed a Special Committee on Nuclear Propulsion, which concluded that British and American nuclearpowered vessels were safe. But public opinion was still in favour of the ban and, as Kate Dewes (2012: 117) concludes: '[T] he report was so aggressively pro-nuclear the government did not risk using it and instead quietly buried it.'

The next major challenge to the policy did not come until the 2005 election, when newly elected National Party leader Don Brash raised the possibility of holding a referendum on the nuclear-free stance. National commissioned another review, which recommended that the law be repealed and replaced with a ban as a matter of policy only. In August 2005, Brash said National might change the law without a referendum if it had a 'clear mandate' to do so. And, during the 2005 election campaign, it emerged that, in January 2004, Brash had apparently told a visiting US congressional delegation that if he were elected, the nuclear-free policy would be 'gone by lunchtime'. After 15 years of relative peace, the nuclear issue was squarely back in the heart of electoral politics.

On the campaign trail, Labour prime minister Helen Clark used the difference over antinuclear policy as a stick to beat Brash. Launching Labour's foreign policy, Clark described the nuclear stance as 
an important symbol of New Zealand's values in the twenty-first century ... New Zealand has built a reputation as a country which makes a strong contribution to international affairs and which is prepared to think and speak for itself. (New Zealand Labour Party 2005)

Her foreign minister, Phil Goff, said the antinuclear position was

part of the way we see ourselves, part of the way we promote ourselves to the world - and for many New Zealanders it is also symbolic of New Zealand's right to make its own decisions. (quoted in Capie 2006: 322)

After National was narrowly defeated on election day, party strategist Murray McCully conceded foreign policy issues 'played a big part' in the outcome (Capie 2006: 326).

Brash was replaced as party leader with John Key, who quickly stated that if National were elected to government he had no plans to change the nuclear-free policy. McCully told US officials in February 2006 that the shift sought to 'clarify existing policy by removing any reference to a possible referendum on whether to repeal the legislation' (Wikileaks 2006). As a US embassy cable noted, however:

While at first glance the potential change seems significant, in reality it was always unlikely National could meet the current policy's pre-condition of public support for a vote. It was even less likely the result would be a majority vote in favor of removing what many see as an iconic piece of legislation. (Wikileaks 2006)

In 2007, on the twentieth anniversary of the law, McCully conceded that the National Party did not easily embrace the nuclear-free legislation, but 'the retention of this legislation that is called iconic, and that is symbolic of our independence of thought and judgment in international affairs, is not in question' (New Zealand Parliament 2007).

On 8 June 2017, the New Zealand Parliament passed a motion to commemorate the thirtieth anniversary of the antinuclear legislation. It reflected the high degree of support for the policy among parties across the political spectrum. National Party foreign affairs minister Gerry Brownlee called the nuclear-free legislation 'a defining aspect of this country's international reputation' (Brownlee et al. 2017: 18671). Kennedy Graham (2017), a Green MP, called it 'something we all take pride in'. This convergence also underlined the remarkable shift that had taken place in New Zealand politics around the policy. 


\section{Analysis and conclusions}

At one level, evaluating the programmatic success of New Zealand's nuclear-free policy is a fairly simple endeavour. Since the legislation was passed, no nuclear weapons or nuclear-powered vessels have entered New Zealand's territory. Since 1990, successive New Zealand governments from across the political spectrum have proclaimed their support for the law. Even as New Zealand and the United States moved to normalise their defence relations after 2006, there was no serious prospect that the legislation would be revoked or amended.

If New Zealand's position has remained consistent, the United States has, arguably, 'blinked'. Secretary of state Hillary Clinton visited New Zealand in 2010 and signed the 'Wellington Declaration', which set out a new program of joint security initiatives, mostly focused on nontraditional security issues in the South Pacific. In 2012, the Washington Declaration relaunched more traditional defence activities, including cooperating on 'deployable capabilities, in support of peace and security in the AsiaPacific' (USNZ Council 2012). In 2012, the Royal New Zealand Navy was welcomed back to the largest US-led military exercise, the Rim of the Pacific (RIMPAC), in Hawai'i. A US Navy vessel, USS Sampson, berthed in New Zealand in 2016 - the first in more than 30 years-and polls indicated 75 per cent of New Zealanders approved of the visit. Remarkably, in 2017, a Royal New Zealand Navy frigate, Te Kaha, was embedded with the nuclear-powered USS Nimitz aircraft carrier for operations in the Sea of Japan. New Zealand is not a formal US ally but now has closer defence relations with the United States than it has had for more than four decades. All of this has happened while New Zealand's nuclear-free policy remains in place.

Whether the policy has achieved 'valuable impacts' is more debatable. US surface vessels have not carried nuclear weapons since 1994. Given nuclear-powered, ballistic missile-carrying submarines rarely visit foreign ports, it is extremely unlikely nuclear weapons would have entered New Zealand territory after that date anyway-law or no law. If the policy was supposed to function as a symbol of opposition to nuclear weapons and deterrence more generally, arguably, it has had little to no impact. The number of de facto nuclear weapon states in the world has increased by three since 1987 (India, Pakistan and North Korea). Nuclear alliances continue to be salient for many states, including New Zealand's closest 
partner, Australia. Attitudes to nuclear power remain mixed, although concerns about climate change and carbon emissions have certainly improved the image of the industry in recent years.

Assessing the nuclear-free policy's success from a process perspective is less complicated. If opposition to nuclear weapons had emerged as a widely held position among New Zealanders by the 1970s, formal development of government policy after Labour won the 1984 election was chaotic and confused. Much of the blame here seems to belong to David Lange. The Cabinet meeting that led the government to turn away the USS Buchanan and commit to the 'nuclear-capable' formulation is one of the clearest examples. Lange shared almost no information about the ship visit he had encouraged and was away, incommunicado, for the week before one of the most consequential decisions in the country's history was taken. At the Cabinet meeting itself:

no Ministers had been briefed and no Ministers had any papers on the [ship visit] request ... In this case the methodical Cabinet processcirculation of papers, Cabinet committee consideration and decision in Cabinet itself were bypassed in the panic over party unity. (Hensley 2013: 106-7)

Amid the confusion, one group of backbenchers seized their moment and showed that clear policy formulation backed with strong arguments could make the difference in winning support for policy change.

Opinion polls showed New Zealanders wanted to have their cake and eat it, too: to ban 'nuclear ships' but to stay in ANZUS. If such a compromise were possible (and some in the fourth Labour Government believed it was) then such an aim was not well served by the policy process that led to the refusal of the USS Buchanan.

All this notwithstanding, it is hard to conclude that the policy has been anything other than an astonishing political success. One clear indicator is the way that even parties which originally opposed the nuclear-free position have recalibrated their stance to be more accommodating towards it. Indeed, rather than simply just tolerating the antinuclear position, there are striking examples of National Party governments going out of their way to play up the importance of New Zealand's antinuclear credentials. Jim Bolger, for example, who had vowed to reverse the policy until just a few weeks before the 1990 general election, told US president George H. W. Bush in a September 1991 meeting that 'New Zealand as 
an identified, high-profile, non-nuclear nation could play a constructive role in promoting the non-proliferation agenda which both New Zealand and the US pursued' (Bolger 1998: 149). In 1995, Bolger's government further embraced the antinuclear identity and took France to the International Court of Justice to try to end nuclear testing in Polynesia.

Arguably, this brand became even more valuable after 11 September 2001, as the United States became more anxious about nuclear proliferation and terrorists accessing weapons of mass destruction. In 2010, New Zealand was one of a group of nations invited to attend the first Nuclear Security Summit in Washington, DC. Ironically, as prime minister Key recalled: 'The first time President Obama rang me, the first thing he raised was New Zealand's anti-nuclear stance and the important role that that played in the world' (Young 2010). In 2017, the Key-English Government supported the development of the Nuclear Weapons Convention - a treaty to ban all nuclear arms - and supported it despite the opposition of the United States and Australia. In February 2018, Prime Minister Jacinda Ardern pledged that

disarmament is as vital today as it was when Norman Kirk and David Lange proclaimed New Zealand's opposition to nuclear weapons and nuclear testing in the Pacific. In a modern context, the greatest challenge comes from North Korea, situated right here in our region. (Ardern 2018)

This case also shows that a test of a policy's durability can also emerge in surprising ways. The election of Brash as National Party leader in 2003and his leaked comment that were he to become prime minister the policy would be 'gone by lunchtime'- thrust the nuclear issue back to the heart of electoral politics. It raised real questions about the extent of public support for the policy, especially given changes in world politics since 1987. But the fact the issue cost National votes and played an important role in its narrow defeat in the 2005 election left party leaders determined to take away what they saw as one of Labour's 'strongest weapons' (Wikileaks 2006). The result was the unconditional support for the status quo offered by new leader John Key in November 2006. The policy had become untouchable.

New Zealand's nuclear-free legislation emerged from a highly contested, confusing, even chaotic political and policymaking process and was helped in important ways by some remarkable, unanticipated events. Despite this, it has overcome political challenges, built a broad coalition of supporters and achieved something remarkable: it has come to be seen as 
something more than a policy-an untouchable symbol of independence and nationhood. There are perhaps few replicable lessons for other areas of public policy in New Zealand's nuclear-free experience, but, if nothing else, this case does illustrate that it is possible to bring about and sustain dramatic change, even when powerful international actors and entrenched bureaucratic interests favour the status quo.

\section{References}

Ardern, J. 2018. Speech to New Zealand Institute of International Affairs. 27 February. Wellington: New Zealand Government. Available from: www. beehive.govt.nz/speech/speech-new-zealand-institute-international-affairs-2.

Baker, R. W. (ed.) 1991. Australia, New Zealand and the United States: Internal change and alliance relations in the ANZUS states. New York: Praeger.

Bassett, M. 2002. The collapse of New Zealand's military ties with the United States. Fulbright Lecture, Georgetown University, Washington, DC, 2 December. Available from: www.michaelbassett.co.nz/articles.php?a=fulbright.

Bolger, J. 1998. A View from the Top: My seven years as prime minister. Auckland: Viking Press.

Brownlee, G., Graham, K. and Flavell, T. U. 2017. New Zealand Parliamentary Debates: Motions-New Zealand Nuclear Free Zone, Disarmament, and Arms Control Act 1987. 30th anniversary (8 June) 723, 18671. Available from: www.parliament.nz/en/pb/hansard-debates/rhr/document/HansS_2017 0608_050550000/brownlee-gerry-graham-kennedy-flavell-te-ururoa.

Capie, D. 2006. 'Gone by lunchtime: New Zealand's foreign policy consensus and the 2005 election.' In S. Levine and J. Johansson (eds), The Baubles of Office: The New Zealand general election of 2005. Wellington: Victoria University Press.

Capie, D. 2009. 'New Zealand and the world: Imperial, international and global relations.' In G. Byrnes (ed.), The New Oxford History of New Zealand. Oxford: Oxford University Press.

Catalinac, A. 2010. 'Why New Zealand took itself out of ANZUS: Observing "opposition for autonomy" in asymmetric alliances.' Foreign Policy Analysis 6: 317-38. doi.org/10.1111/j.1743-8594.2010.00115.x.

Clements, K. 2015. Back from the Brink: The creation of a nuclear free New Zealand. Wellington: Bridget Williams Books. 


\section{SUCCESSFUL PUBLIC POLICY}

Dewes, K. 2012. 'Peace and disarmament activism.' In J. Headley, A. Reitzig and J. Burton (eds), Public Participation in Foreign Policy. London: Palgrave Macmillan.

Evans, C. 1987. 'New Zealand nuclear aversion.' The New York Times, 14 June.

Graham, K. 1987. 'New Zealand's non-nuclear policy: Towards global security.' Alternatives 12(2): 217-42.

Graham, K. 2017. 'NZ zone a precursor to a total nuclear weapon ban.' Green Blog, 14 June. Wellington: The Green Party of Aotearoa New Zealand. Available from: blog.greens.org.nz/2017/06/14/nz-total-ban-nuclear-weapons/.

Hager, N. 2011. Other People's Wars: New Zealand in Afghanistan, Iraq and the war on terror. Auckland: Craig Potton.

Hensley, G. 2013. Friendly Fire: Nuclear politics and the collapse of ANZUS, 1984-1987. Auckland: Auckland University Press.

International Atomic Energy Agency (IAEA) 2011. 'Updates of 12 April 2011.' In Fukushima Nuclear Accident Update Log. Vienna: IAEA.

Lange, D. 1990. Nuclear Free: The New Zealand way. Auckland: Penguin.

Leadbeater, M. 2013. Peace, Power and Politics: How New Zealand became nuclear free. Dunedin: Otago University Press.

Locke, E. 1992. Peace People: A history of peace activities in New Zealand. Christchurch: Hazard Press.

McKinnon, M. 1999. 'Realignment: New Zealand and its ANZUS allies.' In B. Brown (ed.), New Zealand in World Affairs. Volume 3 1972-1990. Wellington: Victoria University Press.

Maclellan, N. 2018. Grappling with the Bomb: Britain's Pacific H-bomb tests. Canberra: ANU Press. doi.org/10.22459/GB.09.2017.

Mydans, S. 1988. 'New Zealand ponders a nuclear survival kit.' The New York Times, 17 February.

New Zealand Labour Party 2005. Nuclear free policy reflects New Zealand's values. Press release, 13 September. Wellington: New Zealand Labour Party. Available from: www.scoop.co.nz/stories/PA0509/S00328.htm.

New Zealand Parliament 2007. New Zealand Parliamentary Debates: MotionsNuclear-free legislation. 20th anniversary (12 June) 639, 9759. 
Phillips, J. 1991. 'New Zealand and the ANZUS alliance: Changing national perceptions, 1945-88.' In R. W. Baker (ed.), Australia, New Zealand and the United States: Internal change and alliance relations in the ANZUS states. New York: Praeger.

Rabel, R. 1991. 'The world turned upside down: Change and continuity in New Zealand politics in the postwar era.' In R. W. Baker (ed.), Australia, New Zealand and the United States: Internal change and alliance relations in the ANZUS states. New York: Praeger.

Rudig, W. 1990. Anti-Nuclear Movements: A world survey of opposition to nuclear energy. Harlow, UK: Longman.

Templeton, M. 2006. Standing Upright Here: New Zealand in the nuclear age, 1945-1990. Wellington: Victoria University Press.

United States New Zealand (USNZ) Council 2012. The Washington Declaration on Defense Cooperation between The Department of Defense of the United States of America and The Ministry of Defense of New Zealand and the New Zealand Defense Force. 19 June. Washington, DC: USNZ Council. Available from: usnzcouncil.org/us-nz-issues/washington-declaration/.

White, R. E. 1997. Nuclear free New Zealand: 1984-New Zealand becomes nuclear free. Working Paper No. 7, July. Auckland: Centre for Peace Studies, University of Auckland.

Wikileaks 2006. National contemplates end of nuke ban in 2006. Cable from Wellington to Washington (Confidential), 17 February. Available from: multimedia.stuff.co.nz/sstimes/cables.pdf.

Williams, M. 2016. 'Nuclear free legacy a source of pride.' Hawke's Bay Today, 30 July.

Wilson, M. A. 1989. Labour in Government, 1984-1987. Wellington: Allen \& Unwin/Port Nicholson Press.

Young, A. 2010. 'Why Obama wants John Key at the summit.' New Zealand Herald, 13 April. 
